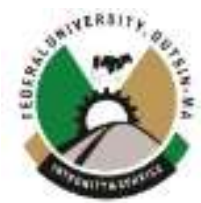

\title{
ECONOMIC ANALYSIS OF STRUCTUTAL CHARACTERISTICS OF POULTRY EGG MARKETING IN KANO METROPOLIS, KANO STATE, NIGERIA.
}

${ }^{1}$ Lawal, A. T., ${ }^{2}$ Yusuf, A. O., ${ }^{1}$ Dambazau, S. A., ${ }^{1}$ Ahmad, Y. S., ${ }^{1}$ Adomi, A. A., ${ }^{3}$ Sadiq, M. S., ${ }^{1}$ Suleiman, I. and ${ }^{4}$ Barau, S.S.

\author{
${ }^{1}$ Department of Agricultural Economics and Extension, Kano Uni. Of Sci \& Tech, Wudil \\ ${ }^{2}$ Agricultural and Rural Management Training Institute (ARMTI), Ilorin, Kwara State, \\ ${ }^{3}$ Department of Agricultural Economics and Extension, Federal University, Dutse, Jigawa State, Nigeria \\ ${ }^{4}$ Department of Agricultural Economics and Extension, Federal University, Dutsinma, Katsina State, Nigeria
}

Corresponding Author's email: altaofeeq2000@yahoo.com, 08035820042

\begin{abstract}
This study analyzed the structural characteristics of poultry egg marketing in five selected markets in Kano metropolis. Data were collected with the aid of questionnaires and were analyzed using descriptive statistics and gini coefficient. The study revealed that all marketers were males with an average age of 38 years and 27 years for wholesalers and retailers respectively. For wholesalers, the average household size is 8 and 5 for the retailers. According to the result, the wholesalers had 15 years as mean years of experience in poultry-egg marketing and retailers have 7 years. The result showed that the average duration of stay of the wholesalers is 15 years and 7 years for retailers. The study showed that $79.5 \%$ of the wholesalers were married and $20.5 \%$ are single while for the retailers $65.9 \%$ are married and $34.04 \%$ are single. The result indicated that about $66.7 \%$ of the wholesalers and $87.2 \%$ are literates. Result of the Gini coefficient analysis showed a high level concentration of 0.48 and 0.54 for wholesalers and retailers. The result shows that $100 \%$ of both wholesalers and retailers have free entry and exit in to the egg market, majority of the wholesalers $(79.5 \%)$ do not belong to any cooperative society, while the remaining $(20.5 \%)$ belong to one or more cooperative societies while $100 \%$ of the retailers do not belong to any cooperative group. It is recommended that good roads and storage facilities should be provided for the people in order to reduce the rate of loss and wastage since egg is perishable.
\end{abstract}

Keywords: Analysis, Structural Characteristics, Poultry Egg, Marketing and Kano Metropolis,

\section{INTRODUCTION}

The Nigerian poultry industry in particular has been rapidly expanding in recent years and is therefore one of the most commercialized (capitalized) subsectors of Nigerian agriculture. Poultry meat and egg play a very useful role in bridging the protein gap in Nigeria. They are palatable and generally acceptable. This acceptability cuts across nearly all cultural and religious boundaries in the country. The production costs per unit remain relatively low, and the return on investment is high. Therefore, farmers need a relatively small amount of capital to start a poultry farm. Also, the production cycle is quite short, so capital is not tied up over a long period. Finally, eggs, one of the major products of poultry production, are more affordable for the common person than other sources of animal protein (Ojo 2003). It gives about $3.5 \mathrm{~g}$ of the total $7.2 \mathrm{~g}$ animal protein requires for individual dietary need per day. It is a good source of several minerals that can be hard to get in other foods, such as iodine and selenium. This is probably one of the reasons why the campaign for one egg per day could not be easily faulted.

The importance of poultry to the national economy cannot be overemphasized, as it has become popular industry for the small holders that have great contribution to the economy of the country. The enterprise has assumed greater importance in improving the employment opportunity and animal protein production in Nigeria. To this end, an up to date knowledge of the profitability and efficiency of resource utilization in the industry will go a long way in bridging some knowledge gap and help in formulating policies aimed to ensure increased and more profitable poultry marketing in the country. Marketing is concerned with all stages of operatives which include the movement of commodities from the farms to the consumers. It involves the performance of all activities involved in the flow of goods and services from the point of initial production until they are in the hands of the ultimate consumers. Most of the eggs marketed and consumed in Nigeria come from poultry birds. Only little attention is given to other sources such as ducks, turkey, guinea fowl and geese because of their ability to lay few eggs.

In a free market economy, the price system and competition provide the coordination mechanism for determining the flow of resources into production and the flow of goods and services into use. It is within the marketing system that prices, allocation of resources, income distribution and capital formation are determined. Therefore the structure and performance of 
marketing system may have some significant effect on the total production of a given commodity on consumer prices, on adoption of improved technology in marketing methods and upon the growth and development of the entire economy, (Olukosi et al, 2007). Over the last decade, the consumption of poultry products in developing countries has grown by $5.8 \%$ per annum, faster than that of human population growth, and has created a great increase in demand (FAO 2011).

Poultry keeping is making an important contribution to the livelihood of the most vulnerable rural households in developing countries. In a study on income generation in trans migrant farming systems in East-Kalimantan, Indonesia, family poultry generated about $53 \%$ of the total income, which was used for food, school fees and expected expanses such as medicines (FAO 2011). Poultry production is no doubt one of the most important ways of alleviating the scourge of protein deficiency in Nigeria and other developing countries. The contribution of poultry products (meat and eggs) to total livestock output increased from $26 \%$ in 1995 to $27 \%$ in 1999 while increase in production of eggs alone accounted for about $13 \%$ during the same period (Ojo, 2003). Nutritionally, eating an egg per day is a good way of putting proteins, fats, vitamins and minerals in human diet. According to Binuomote et al, (2008) a medium sized egg supplies about 80 calories of energy to our body. The author further asserted that egg contains not only a trace of carbohydrate, but it was also adjudged to be a replacement for meat as it contains all essential amino-acids in adequate proportion required by the body for general growth and repair. It is also a source of vitamin A which protects against night blindness and prevents skin infections. It has been described as the source of income to the poultry egg marketers (Adetimirin, 2000).

The structure of the market, which refers to how the market is functioning, is the concept behind the industrial organization theory. Based on the industrial organization theory, the structure of a market has an influence on the strategy and decision making of a company in terms strategic supply management (Raible, 2013). According to Tiku et al, (2012), market structure is mostly measured by the Gini coefficient and Lorenz curve. The Gini coefficient expresses the extent to which the market is concentrated. It ranges from zero to one, with zero indicating perfect equality in the size and distribution of buyers or sellers, and one implying perfect monopsony/monopoly in the market. Therefore, this study describes the socio-economic characteristics of egg marketers and describes and determines structure of egg marketing in the study area.

\section{METHODOLOGY}

\section{Study Area}

The study area for this research was Kano metropolis of Kano State. Kano metropolis comprises of eight local governments areas, they include Dala, Kumbotso, Gwale, Kano municipal, Tarauni, Fagge, Ungogo and Nassarawa local governments areas. The areas used for the study were and Rimi market in Kano municipal, Yankaba market in Nassarawa local government, Tarauni market in Tarauni local government, Singa market and an egg depot in Katsina road which are under Fagge local government area.

In Singa market, there was a place called "Yan kwai" where only egg marketers operate. There were large number of both wholesalers and retailers operating in the market. The egg depot in Katsina road was found adjacent to Niger Republic consulate office. The depot used to operate in Bello road before recently moving to the new destination. The marketers operating in the depot are only wholesalers with large number of labourers carrying out the loading and off-loading of eggs. The commodities found in Yankaba market were mostly foodstuff such as fruits, vegetables, cereals, poultry meat and egg etc. The egg marketers were found in the midst of the vegetable traders. In Tarauni market, the commodities found includes agricultural commodities like foodstuff such as vegetables, fruits, cereals and livestock product such as poultry, fish etc. Rimi market was found along Murtala Muhammad hospital way. The commodities found in the market include foodstuff like grains, vegetables, poultry product, fish, beef, etc. There was an area in the market around Darma where the major wholesalers operate.

\section{Sampling Techniques}

In Kano metropolis there are so many markets, for this study five markets were purposely selected based on concentration and intensity of egg marketing. The markets were Yankaba, Tarauni, Rimi, Singa, and Katsina road. In four of the markets, the egg marketers are stratified with wholesalers and retailers and only wholesalers in one. A simple census of egg marketers was conducted in each of the six markets and thirty nine (39) and forty seven (47) of wholesalers and retailers respectively were found in all the markets, giving a total of eighty six (86) egg marketers for the study. 
Table 1: Sample Frame of Poultry Egg Marketers (Wholesalers and Retailers)

\begin{tabular}{lllll}
\hline S/N & Markets & No of wholesalers & No of Retailers & Frequency \\
\hline 1 & Yankaba & 4 & 8 & 12 \\
2 & Tarauni & 2 & 10 & 12 \\
3 & Rimi & 4 & 15 & 19 \\
4 & Singa & 21 & 14 & 35 \\
5 & Katsina road & 8 & 0 & 8 \\
& Total & 39 & 47 & 86 \\
\hline
\end{tabular}

\section{Method of Data Collection and Analysis}

The data for the study was obtained using primary sources. It was collected using a well-structured questionnaire which was administered to the Poultry Egg Marketers (Wholesalers and Retailers) The questionnaire elicits information on socioeconomic characteristics of egg marketers, market structure, conduct and performance, and other relevant information on the marketing of eggs in Kano metropolis. Descriptive statistics was used to describe the socio-economic characteristics of egg marketers, it involves the used of mean, frequency distribution and percentages and Gini coefficient was also used in analyzing the data.

This was used to measure the market structure of egg marketers. It is expressed as;

\section{RESULTS AND DISCUSSION}

Socio-economic Characteristics of Poultry Egg Marketers
$\mathrm{G} . \mathrm{C}=1-\sum X Y$

G.C $=$ Gini coefficient

$\mathrm{X}=$ the percentage of poultry egg marketers,

$\mathrm{Y}=$ the cumulative percentage of their sales or revenue

Gini coefficient ranges between 0 and 1 . A Gini Coefficient of 0 implies a perfect equality distribution; while a coefficient of 1 means perfect inequality distribution. The closer the Gini coefficient is to zero, the greater the degree of equality and the lower the level of concentration and the more competitive are the markets (Haruna et al, 2012). Putting it differently a higher Gini Coefficient means higher level of concentration and consequently high inefficiency in the market structure.

Table 2: Distribution of poultry egg Marketers according to their socio-economic variables (Quantitative)

\begin{tabular}{lccccccccc}
\hline & \multicolumn{1}{c}{ Wholesalers } & \multicolumn{4}{c}{ Retailers } \\
Variables & Min Max Mean SD & \multicolumn{1}{c}{ Min Max Mean SD } \\
\hline Age (years) & 22 & 60 & 38 & 9.3 & 20 & 35 & 27 & 3.6 \\
Household size( No) & 2 & 18 & 8 & 3.9 & 2 & 8 & 5 & 1.5 \\
Years of experience & 5 & 35 & 15 & 8.3 & 2 & 10 & 7 & 2.7 \\
Duration of stay( years) & 5 & 35 & 15 & 6.8 & 2 & 10 & 7 & 2.7
\end{tabular}

Age is the amount of time expressed in years someone spends on earth or how long somehow has existed. As indicated in table 2 , the results of the study revealed that the mean age of the egg marketers was 38 years for wholesalers and 27 years for retailers. Age plays a significant role in egg marketing. The more energetic an individual is, the higher the possibility of his or her to perform better than the very young or very old marketers. Afolanbi, (2007) also reported that age of marketers have positive impact on the business aggressiveness and flexibility in marketing activities. The results of the study revealed that the egg marketers have a household size mean of 8 for wholesalers and 5 for retailers. The household size affect the managerial of marketing through understanding of more responsibility in terms of high number of population in household size which lead to spending most of the earning/profit to family instead of expanding the capital, It also determines the size of marketing either big or small. This result to some extent agrees with the findings of Onwumere et al, (2009) which shows that majority of marketers have household size of 2-11.

According to the result, the wholesalers have 15 years as mean years of experience in poultry-egg marketing and retailers have 7 years. The result suggests that majority of the poultry-egg marketers in the area are fairly new entrants into the business. It is generally expected that productivity increases with years of experience. Experience in marketing is a key factor in marketing efficiency, margin, and the longer the years of marketing experience, the more exposed the marketer becomes and the more efficient and effective the marketer is expected to be in allocation of resources. Duration of stay refers to the period a person has been operating in a particular market. The result shows that the average duration of stay of the wholesalers is 15 years and 7 years for retailers. The table shows that the wholesalers have minimum duration of 5 years and maximum 
of 35 years and 2 years and 10 years for the retailers

respectively.

Table 3: Distribution of poultry egg Marketers according to their socio-economic variables (Qualitative)

\begin{tabular}{lcccc}
\hline \multirow{2}{*}{ Variable } & \multicolumn{2}{c}{ Wholesalers } & \multicolumn{2}{c}{ Retailers } \\
& Frequency & Percentage $\%$ & Frequency Percentage $\%$ \\
Marital Status & & & & \\
Married & 31 & 79.5 & 31 & 65.9 \\
Single & 8 & 20.5 & 16 & 34.04 \\
Level of education & 12 & 30.8 & 16 & 34.0 \\
Primary education & 9 & 23.1 & 19 & 40.4 \\
Secondary education & 5 & 12.8 & 6 & 12.8 \\
Tertiary education & 13 & 33.3 & 6 & 12.8 \\
Islamic education & 3 & & & \\
Other source of income & 1 & 7.7 & 3 & 6.4 \\
Trading & 35 & 89.7 & 4 & 8.5 \\
Agricultural production & & & 40 & 85.1 \\
None & & & & \\
& & & & \\
\hline
\end{tabular}

The result shows that $100 \%$ of both wholesalers and retailers are males, which means that males dominated the egg market for both wholesalers and retailers. Domination of many agricultural businesses by males is a common occurrence in northern Nigeria. This has to do with culture and religion of the people dominating Kano metropolis, Fidelia (2005). The distribution of marketers based on marital status as indicated in the table shows that $79.5 \%$ of the wholesalers are married and $20.5 \%$ are single while for the retailers $65.9 \%$ are married and $34.04 \%$ are single. Research revealed that marital status to some extent influences the population of marketers for marketing purposes because the marriage institutions possess some restrictions as regard to which marketer is responsible and trustworthy. This research agrees with the findings of U.N. (2007) that different ethnoreligious group continues to attach prestige to marriage as an indicator of social responsibility, trust and achievement. According to the results, it can be deduced that (33.3\%) of the wholesalers had religious education and $(40.4 \%)$ of retailers had secondary education. Those who had only tertiary, secondary and primary education were $12.8,23.1 \%$ and $30.8 \%$ respectively for wholesalers and those retailers who had primary, tertiary and religious were $34.0 \%, 12.8 \%, 12.8 \%$ respectively. This indicated that about $66.7 \%$ of the wholesalers and $87.2 \%$ are literates. The literacy level of the wholesalers would afford them the opportunity to understand and adopt modern marketing services thereby enhancing profitability. Other studies such as Afolami (2007), found that education level influenced productivity and market access. Source of income simply means where a person's money is coming from. Most of the egg marketers do not engage in other activities besides egg marketing. $7.7 \%$ and $2.6 \%$ of the wholesalers partake in trading and crop production respectively and $6.4 \%$ and $8.5 \%$ for the retailers respectively. The result shows that $89.7 \%$ and $85.1 \%$ of the wholesalers and retailers depend heavily on egg marketing. This is in line with the findings of (Fatima, 2016) which implies that majority of agricultural marketers would not engage in other occupations.

\section{Market Structure and Conduct}

Market structure consists of the relatively stable features of the environment that influence the behavior and rivalry among the buyers and sellers operating in a market. Market conduct refers to the price and other market policies which are pursued by market players and the way in which they coordinate their decisions.

\section{Gini coefficient}

Gini coefficient was used to examine the market concentration for poultry eggs in order to determine the degree of competition or monopoly in the market. 
Table 4a: Determination of market concentration for wholesalers

\begin{tabular}{lccccccc}
\hline $\begin{array}{l}\text { Quantity } \\
\text { sold }\end{array}$ & $\begin{array}{c}\text { No of seller } \\
\text { (freq) }\end{array}$ & $\begin{array}{c}\text { Prop } \\
(\mathrm{x})\end{array}$ & $\begin{array}{c}\text { Cumulative } \\
\text { prop }\end{array}$ & $\begin{array}{c}\text { Total sales } \\
\text { total sales }\end{array}$ & $\begin{array}{c}\text { Pro } \% \\
(\mathrm{Y})\end{array}$ & $\Sigma \mathrm{XY}$ \\
\hline$<5000$ & 9 & 0.230 & 0.230 & 25380 & 0.054 & 0.054 & 0.001 \\
$5001-10000$ & 7 & 0.179 & 0.409 & 59800 & 0.128 & 0.182 & 0.030 \\
$10001-15000$ & 6 & 0.153 & 0.562 & 81320 & 0.175 & 0.357 & 0.054 \\
$15001-20000$ & 17 & 0.435 & 1 & 298000 & 0.641 & 1 & 0.43 \\
Total & 39 & 1 & & 464500 & 1 & & 0.515 \\
\hline
\end{tabular}

G.C $=1-\Sigma X Y$

G.C $=1-0.515$

$=0.48$

Table 4b: Determination of market concentration for retailers

\begin{tabular}{cccccccc}
\hline $\begin{array}{c}\text { Quantity } \\
\text { sold }\end{array}$ & $\begin{array}{c}\text { No of seller } \\
\text { (freq) }\end{array}$ & $\begin{array}{c}\text { Prop Cumulative } \\
(\mathrm{x})\end{array}$ & prop & \multicolumn{3}{c}{ Total sales Prop } & \multicolumn{2}{c}{ Cumm.prop } & XY \\
total sales & $(\mathrm{Y})$ & \\
\hline$<201$ & 16 & 0.340 & 0.340 & 3040 & 0.220 & 0.220 & 0.06 \\
$201-300$ & 5 & 0.106 & 0.446 & 1360 & 0.098 & 0.318 & 0.03 \\
$301-400$ & 25 & 0.531 & 0.977 & 5320 & 0.385 & 0.703 & 0.35 \\
$401-500$ & 1 & 0.021 & 1 & 4080 & 0.30 & 1 & 0.02 \\
Total & 47 & 1 & & 13800 & 1 & & 0.46 \\
\hline
\end{tabular}

G.C $=1-\Sigma X Y$

$=1-0.46$

G.C $=0.54$

Result of the Gini coefficient analysis showed a high level concentration of 0.48 and 0.54 for Wholesalers and Retailers as shown in Table $2 \mathrm{a}$ and $\mathrm{b}$. This concentration ratio indicates that there is a high level of inequality in the sales revenue of the respondents. More so, the result showed that the market is imperfectly competitive with a structure that suggests a monopolistic market. The Gini coefficient has been used by several researchers to determine the market structure for different agricultural commodities. Tiku et al. (2012) found a Gini coefficient of 0.65 and 0.54 for merchants and processors respectively, indicating an oligopoly market structure among palm oil marketers in Cross River State, Nigeria. However, different and contrasting results were reported by Enibe, et al, (2008) in the case of banana marketing in Anambra State, Nigeria where the Gini coefficients were 0.21 and 0.17 for wholesalers and retailers respectively, depicting a competitive market. Haruna, et al, (2012) made a similar observation in their study on the Market structure, conduct, channels and margins of dry season Okra vegetable in South-Eastern Nigeria. 
Table 5: Distribution of poultry egg Marketers according to their Market conduct

\begin{tabular}{|c|c|c|c|c|}
\hline \multirow[b]{2}{*}{ Variable } & \multicolumn{2}{|c|}{ Wholesalers } & \multicolumn{2}{|c|}{ Retailers } \\
\hline & Frequency & Percentage & Frequency & Percentage \\
\hline \multicolumn{5}{|l|}{ Source of Information } \\
\hline Cooperatives & 4 & 10.3 & 0 & 0 \\
\hline Colleagues & 35 & 89.7 & 47 & 100 \\
\hline \multicolumn{5}{|c|}{ Cooperative membership } \\
\hline Member & 8 & 20.5 & 0 & 0 \\
\hline Non-Member & 31 & 79.5 & 47 & 100 \\
\hline \multicolumn{5}{|l|}{ Price Allocation } \\
\hline Negotiation & 8 & 20.5 & 0 & 0 \\
\hline Market & 31 & 79.5 & 47 & 100 \\
\hline \multicolumn{5}{|l|}{ Mode of payment } \\
\hline Cash & 24 & 61.5 & 28 & 59.9 \\
\hline Credit & 0 & 0 & 8 & 17.0 \\
\hline Both & 15 & 38.5 & 11 & 23.4 \\
\hline \multicolumn{5}{|l|}{ Physical treatment } \\
\hline Sorting & 26 & 66.7 & 0 & 0 \\
\hline Grading & 13 & 33.3 & 0 & 0 \\
\hline Packaging & 0 & 0 & 47 & 100 \\
\hline \multicolumn{5}{|l|}{ Source of finance } \\
\hline Relatives and friends & 26 & 66.7 & 47 & 100 \\
\hline Money lender & 13 & 33.3 & 0 & 0 \\
\hline
\end{tabular}

\section{Access to market information}

This refers to the market intelligence and also refers to the marketer's access to information both within and outside the market in which they participate and it is the fourth determinant of the structure that a particular commodity market can assume (Mohammed, 2013). The results show that $100 \%$ of both wholesalers and retailers have fast access to information. Umeh et al, 2008 observed that well analyzed, historical market information enables marketers to take appropriate decisions.

\section{Source of the market information}

The result shows that $10.3 \%$ of wholesalers get information from cooperatives and $89.7 \%$ gets their information from colleagues in the market while $100 \%$ of the Retailers get their information from colleagues in the market. This implies that majority of the egg marketers source their information from other marketers. This is in line with the findings of Bature (2015) which implies that majority of marketers' source their information from other colleagues.

\section{Entry and exit}

This refers to the presence or otherwise of barriers to marketers entry or exit from the market and it is the third factor that determines the structure that a particular market can assume (Olukosi et al, 2007). The result shows that $100 \%$ of both wholesalers and retailers have free entry and exit in to the egg market. This study is in line with the findings of Bature (2015) which suggests that majority of marketers have free entry and exit in the markets.

\section{Cooperative membership}

In a market setup, cooperatives tend to influence how the market performs by influencing the conduct of the market participants. The result shows that majority of the wholesalers $(79.5 \%)$ do not belong to any cooperative society, while the remaining (20.5\%) belong to one or more cooperative societies while $100 \%$ of the retailers do not belong to any cooperative group Market cooperatives and social groups tend to exhibit collusive behavior in terms of market and pricing policies pursued by the actors and the way they coordinate their decisions. This collusive behavior is characterized by firms or individuals coming together and agreeing to fix output quotas, set prices and avoid competitive pressures, as a way of increasing profits, leading to higher prices in the market. Membership of cooperative societies is believed to enhance the sharing of information on improved technologies through interactions as well as easing inputs acquisition and utilization constraints faced by decision makers (Effiong, 2008).

\section{Ways of price allocation}

Price allocating refer to the way marketers arrived at operating price of their egg. Pricing strategy is described as predatory, exclusive and collusive in the conduct approach in descriptive and organizational market analysis. The results shows that $20.5 \%$ of wholesalers allocate prices through negotiation while $79.5 \%$ and $100 \%$ of wholesalers and retailers respectively allocate prices based on computing cost of marketing. This shows that majority of the egg marketers rely on what happen in the marketing cost. Marketers take advantage of period of glut to influence the price and output resulting in a level of profit over and above marketing cost. Smith (1981).

\section{Mode of payment}


The Mode of payment refers to the way the egg marketers purchase the egg from their sources. According to the results, $61.5 \%$ and $59.9 \%$ of wholesalers and retailers respectively mode of payment is through the use of cash, while $38.5 \%$ and $23.4 \%$ of wholesalers and retailers source their eggs through the use of both cash and on credit. The result shows that only $17 \%$ of retailers purchases their egg through credit alone with the intend of paying after selling the eggs. Credit sale is probably possible because the marketers have strong social alliances that exist among themselves and these alliances were based on friendship, credit, and kinship (Adeiza, 2013).

\section{Physical treatment}

Physical treatment refers to any activity that egg marketers carry out on the eggs in order to improve their market potentials. The result shows that $66.7 \%$ and $33.3 \%$ of the wholesalers sort and grade their eggs respectively while the retailers package the eggs in nylons and polythene bags. This is in line with the findings of
Adeiza (2013) which implies that value is added to products which in return attracts consumers which has influence on easy sale of egg and their profit.

\section{Source of finance}

The initial capital reflects the ability of the business to expand and capture more profit. It also indicates the survivability of the business over a period of time considering all the uncertainties inherent in marketing. The result shows that $33.3 \%$ of wholesalers source their finance from money lenders and $66.7 \%$ and $100 \%$ of wholesalers and retailers source the finance from relative and friends respectively. This is not in agreement with Tsado et al, 2009 in the study carried out on sustainability extension activities in yam production an assessment of the productivity of farmers' constraints of Yagba local government area of Kogi State which revealed that $67.25 \%$ of the respondents source their capital from cooperatives.

Table 6: Distribution of egg marketers according to main sources of egg

\begin{tabular}{llll}
\hline Category & Main source of egg & Frequency & Percentage \\
& & \\
\hline Wholesalers & Singa Market & 2 & 5.1 \\
& Katsina Road & 1 & 2.6 \\
& Ibadan & 19 & 48.7 \\
& Zamfara & 6 & 15.4 \\
& Jos & 8 & 20.5 \\
Retailers & Yan gamadan & 3 & 7.7 \\
& Singa market & & \\
& Katsina Road & 18 & 38.3 \\
& Gunduwawa & 17 & 36.2 \\
Rimi Market & 7 & 14.9 \\
& 5 & 10.6 \\
\hline
\end{tabular}

The result shows that $48.7 \%$ of the wholesalers source their eggs from Ibadan. $20.5 \%$ from Jos, $15.4 \%, 7.7 \%, 5.1 \%$, and $2.6 \%$ from Zamfara, Yan gamadan, Singa market and Katsina road respectively while for the retailers (38.3\%) and (36.2\%)on the other hand source their eggs from Singa market and Katsina road respectively. 14.9\% from Gunduduwa and 10.6\% from Rimi market. The eggs are being sourced from these sources either due to quality or price of the eggs.

Table 7: Distribution of poultry egg Marketers according to their Mode of transportation

\begin{tabular}{|c|c|c|c|}
\hline & Transport & Frequency & Percentage \\
\hline \multirow[t]{3}{*}{ Wholesalers } & Motor cars & 2 & 5.1 \\
\hline & Motorcycle & 2 & 5.1 \\
\hline & Truck / Vans & 35 & 89.7 \\
\hline \multirow[t]{4}{*}{ Retailers } & Motor cars & 8 & 17.0 \\
\hline & Motorcycle & 16 & 34.0 \\
\hline & Bicycle & 5 & 10.6 \\
\hline & Foot & 18 & 38.3 \\
\hline
\end{tabular}


According to the above result, $5.1 \%$ of the wholesalers used motor cars to transport their eggs to the market, another $5.1 \%$ used motorcycle and majority (89\%) used trucks/vans due to long distance and quantity of the egg to be transported. Majority of the retailers (18\%) transport their eggs using foot due to short distance and quantity of the egg while $17 \%, 34 \%$, and $10.6 \%$ used motor cars, motorcycles and bicycles respectively.

\section{CONCLUSION}

It can be concluded that poultry egg marketing in Kano metropolis is concentration ratio indicates that there is a high level of inequality in the sales revenue of the respondents. More so, the result showed that the market is imperfectly competitive with a structure that suggests a monopolistic market.

\section{RECOMMENDATIONS}

In line with the findings of the study, the following recommendations are put forward.

i. It is recommended that poultry egg marketers be encouraged to increase their scale of marketing for increased profitability. This could be achieved if small scale retailers can come together and pull their resources together and form cooperatives.

ii. It should be advocated to the general public that egg marketing should not be seen as a business for the males only; females can also involve making it decent and admirable.

iii. Good roads and storage facilities should be provided for the people in order to reduce the rate of loss and wastage since egg is perishable

\section{REFERENCES}

Adeiza, A.I. (2013) "Economic Analysis of Cowpea Marketing in Okene Local Government Area of Kogi State, Nigeria". Unpublished B.Ag. Project, Department. of Agricultural Economics and Extension, Bayero University Kano

Adetimirin, O. T. (2000). "Analysis of Egg Marketing in Agege L.G.A of Lagos State, Nigeria." Unpublished B.Tech.Thesis, Department of Agricultural Economics and Extension, Ladoke Akintola University of Technology Ogbomoso.

Afolabi, J.A. (2007). "Evaluation of Poultry Egg Marketing in South-Western Nigeria”. Inter. J. Poultry Sci. 6(7): pp 362-366.

Bature, U.I. (2015). "Economic Analysis of Pineapple Marketing in three Selected Markets of Kano Metropolis, Kano State, Nigeria". Unpublished B.Ag. Project, Department of Agricultural Economics and Extension, Bayero University Kano.

Binuomote, S.O., Ajetomobi, J.O. and Ajao, A.O. (2008). "Technical Efficiency of Poultry Egg Producers in Oyo State, Nigeria.” International Journal of Poultry Science, 7 (12): pp $1227-1231$
Effiong, E. O. and Onuekwusi, G. C. (2007). "Maximum Likelihood Estimation Techniques of Rabbit Production in Akwa Ibom State, Nigeria". Research Journal of Applied Science, 2(2): pp 165-169

Enibe, D.O., Chidebelu, S.A.N.D., Onwubuya, E.A., Agbo, C. and Mbah, A.A. (2008). "Policy Issues in the Structure, Conduct and Performance of Banana Market in Anambra State, Nigeria”. Journal of Agricultural Extension, 12(2): pp 35-39

FAO. (2011). "Mapping Supply and Demand for AnimalSource Foods to 2030. Animal Production and Health Working Paper" No. No 2. http://www.fao.org/docrep/014/i2425e/i2425e00.pdf[accessed July 12, 2015].

Fidelia, D.N. (2005). "Economic Analysis of Cocoa Marketing in Ondo and Ekiti States of Nigeria”. Ph.D Thesis, Unpublished. Department. of Agricultural Economics and Extension, Federal University of Technology Akure, Nigeria.

Haruna, U.; Jibril, S. A.; Kalla, D. J. U. and Suleiman, H. (2012). "Evaluation of Egg Production in Jos North Local Government Area, Plateau State, Nigeria".International Journal of Poultry Science, 6 (8): pp 604 - 607.

Mohammed A.B., Mohammed S.A., Ayanlere A. F., Afolabi O. K., 2013. "Evaluation of Poultry Egg Marketing in Kuje Area Council Municipality of F.C.T Abuja, Nigeria". Greener Journal of Agricultural Sciences. 3(1): pp 068-072, http://dx.doi.org/10.15580/GJAS.2013.1.101112111

Ojo, S.O. (2003). "Productivity and Technical Efficiency of Poultry Egg Production in Nigeria". Int'l. Journal. Poultry. Sci. 2(3): pp 459-464.

Olukosi J.O., Isitor, S. U. and Ode, M. O. (2007). "Introduction to Agricultural Marketing and Prices: Principles and Applications". Living Books Series, G.U. Publications, Abuja, Nigeria.

Onwumere, J. Obasi, R.O. and Nwogu (2009): "Profitability and Viability Analysis of Small holder Cocoa Production three Management Systems in Abia State", J.N. Nmadu, M.A. Ojo, U.S. Mohammed. Proceedings of $11^{\text {th }}$ annual national conference of national association of agricultural economics (NAAE)

Raible, M. (2013). "Industrial Organization Theory and its Contribution to Decisión-Making in Purchasing", B.S. Thesis., University of Twente., Netherlands.

Smith, I.R. (1981): "The Economics of Milk Fish Fry and Fingerlings Industry of the Philippines”. ICLARM Technical 
Reports I. International Centre for Living Aquatic Resources Management, Manila and Aquaculture Department (ICLARM), Southeast Asian Fisheries Development Centre, Iloilo, Philippines.

Tiku, N. E., Olukosi, J.O., Omolehin R.A. and Oniah M.O. (2012). "The Structure, Conduct and Performance of Palm Oil Marketing in Cross River State, Nigeria". Journal of Agricultural Extension and Rural Development, 4(20): pp 569573.

Tsado , J.J.N and Nmadu (2009): "Sustaining Extension Activities in Yam Production": An Assessment of the
Productivity Constraint of Farmers in Yagba Local Government Area of Kogi State.

United Nations Economic Commission for Africa. 2007. "Africa Review Report on Agriculture and Rural Development". United Nations Economic Commission for Africa, Addis Ababa.

Umeh J.C. Adessina, A.C. and Kehinde, A.I. (2008). "Economics of Wholesales Marketing of Fruit in Ibadan Metropolis of Oyo State, Nigeria". 